\title{
Eksplorasi Penalaran Logis Calon Guru Matematika Melalui Pengintegrasian Pendekatan STEM dalam Menyelesaikan Soal
}

\author{
Edy Setiyo Utomo ${ }^{1 *}$, Fatchiyah Rahman ${ }^{2}$, dan Ama Noor Fikrati ${ }^{3}$ \\ Program Studi Pendidikan Matematika, STKIP PGRI Jombang \\ Jalan Pattimura III/20 Jombang, Jombang, Jawa Timur, Indonesia \\ 1edystkipjb@gmail.com, 2fatchiyah.stkipjb@gmail.com,3elfikh@yahoo.co.id
}

Artikel diterima: 30-09-2019, direvisi: 26-01-2020, diterbitkan: 31-01-2020

\begin{abstract}
Abstrak
Rendahnya kemampuan penalaran menjadi penyebab rendahnya prestasi matematika. Diperlukan solusi, diantaranya STEM. Penelitian ini bertujuan mengeksplorasi penalaran logis calon guru matematika melalui pengintegrasian pendekatan STEM dalam menyelesaikan soal matematika. Jenis penelitian yaitu kualitatif dengan pendekatan deskriptif. Subjek penelitian adalah seorang mahasiswa calon guru matematika yang dipilih secara purposive sampling. Instrumen penelitian meliputi utama dan pendukung yaitu TPL dan pedoman wawancara. Teknik analisis data meliputi reduksi data, penyajian data, interpretasi data, dan penarikan simpulan. Hasil penelitian menunjukkan subjek melakukan eksplorasi software Geogebra untuk mengidentifikasi informasi yang diperlukan sesuai pengetahuan yang dimiliki. Subjek juga melakukan beberapa teknik mengoperasikan aplikasi Geogebra, seperti dilatasi dan refleksi. Selanjutnya subjek menekankan beberapa titik-titik koordinat selama membuat grafik fungsi yang ditunjukkan software Geogebra untuk membuktikan jawabannya melalui subtistusi setiap titik-titiknya. Subjek meyakini kebenaran hasil yang ditunjukkan pada Geogebra. Pengintegrasian teknologi dalam setiap matakuliah diperlukan agar mahasiswa dapat mengembangkan penalaran logis dalam menyelesaikan masalah matematika. Kata Kunci: logis, penalaran, STEM.
\end{abstract}

\section{Logical Reasoning Exploration for Mathematics' Candidate Teacher through Integration of STEM Approach in Solving Problem}

\begin{abstract}
The low reasoning ability is the reason for low mathematical achievement. A solution is needed, including STEM. This research has aimed to explore the logical reasoning of mathematics teacher candidate through integrating the STEM approach in solving a math problem in a task. This research uses descriptive qualitative. The subject of this research is the students of the mathematics education program of STKIP PGRI Jombang. These research instruments involve main and supportive that consist of TPL and interview. In analyzing data, it consists of reduction data, presentation data, interpretation data, and conclusion. The result of this research shows that the subject does exploration through "Geogebra" to identify the information which is appropriate with its knowledge. The subject also does several techniques in operating "Geogebra", such as; dilated and reflection. Moreover, the subject emphasizes several coordinate points while making a graphic of function which is shown in "Geogebra", because it is suitable for things that have already done in a worksheet. Integrating technology in each course is needed so that students can develop logical reasoning in solving mathematical problems.

Keyword: logical, reasoning, STEM.
\end{abstract}




\section{Pendahuluan}

Kualitas sumber daya manusia salah satunya ditentukan oleh faktor pendidikan, karena pendidikan dapat meningkatkan pola pikir untuk lebih baik (Alam \& Razak, 2018). Penguasaan teknologi dan keahlian profesional dalam pengetahuan yang luas merupakan indikator kualitas sumber daya manusia. Perguruan tinggi dapat dikatakan sebagai salah satu pencetak kualitas sumber daya manusia, dimana proses pembelajarannya diintegrasikan pada perkembangan teknologi. Kenyatannya, Indonesia sebagai negara yang memasuki era persaingan bebas masih memiliki sumber daya manusia yang rendah. Kualitas sumber daya manusia yang rendah dipengaruhi oleh kualitas pendidikan di Indonesia masih perlu ditingkatkan, terutama pada materi matematika.

Salah satu acuannya, riset PISA pada tahun 2015 yang terbit pada tahun 2016 yang menunjukkan bahwa Indonesia memiliki nilai rata-rata 403 dari rata-rata internasional 500 dan 501 serta data riset TIMSS tahun 2015, Indonesia menempati urutan ke 69 dari 76 negara yang terlibat TIMSS (TIMSS, 2015), sedangkan pada tahun 2018 indonesia memperoleh skor 379 dengan skor rata-rata 489, sehingga indonesia berada pada peringkat 72 dari 78 negara. Menurut Puspitasari \& Ratu (2019) bahwa PISA (Programme for International Student Assessment) adalah studi internasional tentang prestasi literasi membaca, matematika, dan sains siswa sekolah berusia 15 tahun yang diadakan setiap 3 tahun oleh Organisation for Economic Cooperation and Development (OECD). Indonesia rata-rata selalu berada pada urutan sepuluh terbawah dibandingkan negara-negara lainnya terutama pada literasi matematika (Afriansyah, 2016). Hal itu didasarkan pada rendahnya kemampuan siswa dalam soal penalaran dan pemahaman dibandingkan dengan soal pemahaman. Untuk mewujudkan hal tersebut, perlu diterapkan prinsip pendidikan yang tidak hanya berorientasi pada bidang akademik, namun siswa dapat mengaplikasikan dalam kehidupan sehari-hari (Utomo \& Rahman, 2016). Pendekatan STEM (Science, Technology, Engineering, and Mathematics) merupakan salah satu pendekatan yang dapat digunakan dalam pembelajaran dengan prinsip mengaitkan kehidupan sehari-hari, karena siswa dapat mengaplikasikan teknologi dan sains dalam proses pembelajaran terutama dalam mengembangkan keterampilan berpikir kreatif, logis, berkomunikasi dan berkolaborasi (Winarni, Zubaidah, \& Koes, 2016; Utami, Jatmiko, Suherman, 2018).

Pendekatan STEM dapat dijadikan sebagai salah satu reformasi dalam dunia pendidikan, terutama untuk menciptakan sumber manusia yang handal dalam berbagai bidang. Pendekatan STEM mengacu pada empat komponen ilmu pengetahuan, yaitu pengetahuan, teknologi, teknik dan matematika. Sesuai dengan pendapat (Septiani, 2016) bahwa implementasi pendekatan STEM dapat membantu mengembangkan pengetahuan, menjawab pertanyaan berdasarkan penyelidikan atau penalaran, dan dapat membantu untuk mengkreasi pengetahuan yang baru. Pendekatan STEM tidak hanya dapat diterapkan di sekolah dasar dan sekolah menengah, tapi juga dapat diterapkan di perkuliahan bahkan program doctoral. Pendekatan STEM menghubungkan pembelajaran dengan empat komponen 
pengajaran, yaitu science, technology, engineering, and mathematics. Selaras dengan hal tersebut pendekatan STEM dapat dilaksanakan pada tingkat pendidikan formal/di dalam kelas dan tingkat satuan non formal/di luar kelas (Gonzalez dan Kuenzi, 2012). Artinya, pendekatan STEM dapat diterapkan pada berbagai tingkat pendidikan dan multi disiplin ilmu.

Karakteristik pendekatan STEM adanya keterlibatan penalaran dalam pengambilan keputusan terhadap suatu masalah dengan didasarkan pada kenyataan maupun bukti. Sesuai pendapat (Permanasari, 2016) bahwa tujuan pendekatan STEM supaya peserta didik memiliki pengetahuan, sikap, dan keterampilan untuk mengidentifikasi pertanyaan dan masalah dalam situasi di kehidupannya, menjelaskan fenomena alam, mendesain, serta menarik kesimpulan bukti. Berdasarkan hal tersebut adanya keterkaitan yang erat antara STEM dengan penalaran terutama dalam pengambilan keputusan.

Software geogebra merupakan salah satu program komputer yang dapat diaplikasi dalam pembelajaran, dimana software ini mempermudah dalam mempelajari materi matematika terutama yang berkaitan dengan geometri dan grafik. Software geogebra dikembangkan oleh Markus Hohenwarter untuk pembelajaran matematika. Software ini merupakan freeware sehingga dapat diunduh di internet secara gratis. Menurut Rahadyan dkk (2018) bahwa software ini dimanfaatkan untuk menanamkan konsep matematika menjadi dinamik atau dapat berubah sesuai dengan kondisi masalah yang disajikan. Begitu pula untuk bentuk geometri dan grafik dapat dieksplorasi secara dinamik (Ramdhani, 2017), sehingga software ini juga dapat meningkatkan pemahaman terhadap suatu konsep serta mempermudah dalam mengkonstruksi konsep baru. Selain itu, dengan menggunakan software akan meningkatkan kemandirian mahasiswa dalam proses pembelajaran, sesuai dengan pendapat Mardiani (2019) bahwa kemandirian belajar akan meningkatkan prestasi yang tinggi dalam belajar matematika.

Penalaran logis merupakan salah satu jenis penalaran yang menekankan pada bagaimana individu mentransformasikan informasi yang diberikan untuk memperoleh konklusi (Asrawati, 2012). Dengan kata lain, penalaran logis merupakan jenis penalaran yang mengutamakan eksplorasi informasi untuk mendapatkan pengetahuan baru. Penalaran dapat berupa suatu kegiatan, suatu proses, suatu aktivitas untuk berpikir dalam menarik kesimpulan atau suatu pertanyaan yang kebenarannya dibuktikan atau diasumsikan.

Berdasarkan hal di atas, indikator penalaran logis yang diintegrasikan dengan pendekatan STEM dalam menyelesaikan soal matematika mengacu pada aspek-aspek berikut: 1) Aspek Sains (Science): Kemampuan subjek dalam mengeksplorasi informasi sesuai dengan pengetahuan yang dimiliki; 2) Aspek Teknologi (Technology): Kemampuan subjek dalam menentukan software yang dapat mambantu penyelesaian masalah; 3) Aspek Teknik (Engineering): Kemampuan subjek dalam mengoperasikan software dalam mambantu penyelesaian masalah; dan 4) Aspek Matematika (Mathematics): Kemampuan subjek dalam menganalisis dan menyampaikan gagasan untuk mendapatkan dan memeriksa simpulan.

Analisis real merupakan salah satu matakuliah yang terdiri dari 4 SKS pada Program Studi Pendidikan Matematika di STKIP PGRI Jombang. Matakuliah ini lebih 
mengedepankan pada pembuktian teoremateorema, sehingga mahasiswa dituntut mampu mengorganisasikan teorem-teorema sebelumnya untuk membuktikan teorema selanjutnya. Kenyataannya, mahasiswa masih belum bisa mengorganisasikan pengetahuan sebelumnya untuk membuktikan teorema. Artinya, kemampuan penalaran logis mahasiswa angkatan 2017 A dan B dapat dikatakan belum maksimal. Hal tersebut dapat dilihat pada hasil Ujian Tengah Semester Genap 2018/2019, dimana mahasiswa belum menunjukkan alasan yang jelas serta kaitan antar teorema selama pembuktian. Berdasarkan hal tersebut, rumusan permasalahan penelitian ini adalah "Bagaimana penalaran logis calon guru matematika melalui pengintegrasian pendekatan STEM dalam menyelesaikan soal matematika?". Tujuan penelitian ini untuk mengeksplorasi penalaran logis calon guru matematika melalui pengintegrasian pendekatan STEM dalam menyelesaikan soal matematika. Manfaat penelitian ini untuk mendapatakan gambaran secara mendalam mengenai penalaran logis calon guru matematika dengan pendekatan STEM selama menyelesaikan soal matematika. Selain itu, penelitian ini dapat dijadikan acuan untuk mengeksplorasi pemahaman calon guru dalam menggunakan software matematika.

\section{Metode}

Jenis penelitian yang digunakan dalam penelitian ini adalah penelitian kualitatif. Peneliti menggunakan jenis penelitian ini karena penelitian ini relevan dengan tujuan penelitian dan memungkinkan untuk mencapai tujuan tersebut. Sedangkan, tujuan penelitian ini adalah untuk mengetahui dan mendeskripsikan pengintegrasian pendekatan
STEM dengan penalaran logis mahasiswa matematika STKIP PGRI Jombang Tahun Akademik 2018/2019.

Subjek penelitian ini terdiri dari seorang mahasiswa calon guru Program Studi Pendidikan Matematika STKIP PGRI Jombang dengan teknik purposive sampling dari angkatan 2017 A dan B, dimana subjek dipilih berdasarkan kriteria tertentu, yaitu calon subjek menguasai software yang berkaitan dengan matematika. Selain itu, mahasiswa angkatan 2017 sudah menempuh matakuliah teori bilangan dan analisis real, dimana matakuliah tersebut berkaitan erat dengan penalaran saat pembuktian teorema.

Instrumen penelitian terdiri dari instrumen utama dan pendukung. Peneliti merupakan instrumen utama, karena selama berlangsungnya proses penelitian, peneliti sebagai penentu dalam mengumpulkan, mereduksi, menganalisis, dan menyajikan data. Instrumen pendukung penelitian terdiri dari Tes Penalaran Logis (TPL) dan Pedoman Wawancara. Soal tes penalaran Logis (TPL) sebagai berikut.

"Buatlah sketsa grafik fungsi dari $f(x)=$ $2|x|+|x-1|$ dengan menggunakan software yang kamu ketahui!"

Teknik pengumpulan data dalam penelitian ini sebagai berikut: 1) Dilakukan pengambilan data tahap pertama dengan cara subjek diberikan TPL yang disingkronisasikan dengan software. Setelah subjek selesai mengerjakan TPL, diadakan wawancara berbasis hasil pengerjaan TPL; 2) Hasil rekaman ditranskripkan dan dikodekan.

Pengecekan keabsahan data penelitian dilakukan dengan triangulasi waktu, dimana subjek diberikan soal yang setara pada waktu yang berbeda. Jika hasil yang diperoleh pada pertemuan kedua sudah ajeg dengan 
pertemuan pertama, maka data hasil pertemuan pertama dikatakan valid dan yang akan dianalisis. Namun jika hasil pertemuan kedua belum ajeg dengan pertemuan pertama, maka perlu diadakan pengambilan data ketiga untuk melihat keajegan dari ketiga data tersebut.. Analisis data penelitian dilakukan beberapa tahapan, yaitu tahapan reduksi data, pemaparan data, interpretasi data, dan penarikan simpulan.

\section{Hasil dan Pembahasan}

Untuk mengeksplorasi penalaran logis yang diintegrasikan dengan pendekatan STEM dalam menyelesaikan soal matematika yang didasarkan beberapa aspek-aspek yaitu aspek sains (science): kemampuan subjek dalam mengeksplorasi informasi sesuai dengan pengetahuan yang dimiliki; aspek teknologi (technology): kemampuan subjek dalam menentukan software yang dapat mambantu penyelesaian masalah; aspek teknik (engineering): kemampuan subjek dalam mengoperasikan software dalam mambantu penyelesaian masalah; dan aspek matematika (mathematics): kemampuan subjek dalam menganalisis dan menyampaikan gagasan untuk mendapatkan dan memeriksa simpulan. Adapun hasil penelitian berupa wawancara dikodekan dengan bentuk enam karakter berupa huruf dan angka. Misal kode P1P007, artinya Peneliti mengambil data pada pertemuan pertama (1) dan memberikan Pertanyaan pada urutan ke tujuh. Bergitu pula pada kode S1J002, artinya subjek pada pertemuan pertama dan memberikan Jawaban pada urutan pertanyaan kedua.

\section{A. Aspek Sains (Science)}

Aspek Sains yaitu mengenai kemampuan subjek dalam mengeksplorasi informasi sesuai dengan pengetahuan yang dimiliki. Subjek diberikan soal dengan perintah dikaitkan dengan penggunaan suatu aplikasi atau software. Hal tersebut bertujuan untuk melihat bagaimana teknik pembuatan grafik untuk menyelesaikan masalah. Selain itu, peneliti bertujuan untuk mengetahui lebih mendalam penalaran logis subjek terhadap objek yang telah dibuat dengan bantuan dari suatu software. Hasil jawaban subjek mengenai penalaran logis yang tanpa dikaitkan dengan STEM (lihat gambar 1).

Berdasarkan hasil jawaban pada gambar 1, peneliti mengkonfirmasi jawaban yang ditunjukkan pada layar melalui wawancara guna menggali lebih dalam mengenai penalaran logis subjek dalam menyelesaikan soal matematika. Hasil wawancara ditunjukkan sebagai berikut:

P1P001 : coba jelaskan soal nomor 2 ini?

S1J001 : kita diminta untuk menunjukkan grafik dari fungsi $f(x)=2|x|+|x-1|$ dengan menggunakan suatu software

P1P002 : apa yang kamu pahami?

S1J002 : ini ada fungsi nilai mutlak yang terdiri dari $f(x)=2|x|+|x-1|$, jadi ada dua nilai mutlak dengan menggunakan operasi penjumlahan

P1P003 : ok, coba jelaskan hasil jawabanmu!

S1J003 : pertama-tama saya mengetik $f(x)=$ $2|x|+|x-1|$ di sini (dengan menunjukkan pada bagian kiri atas dari

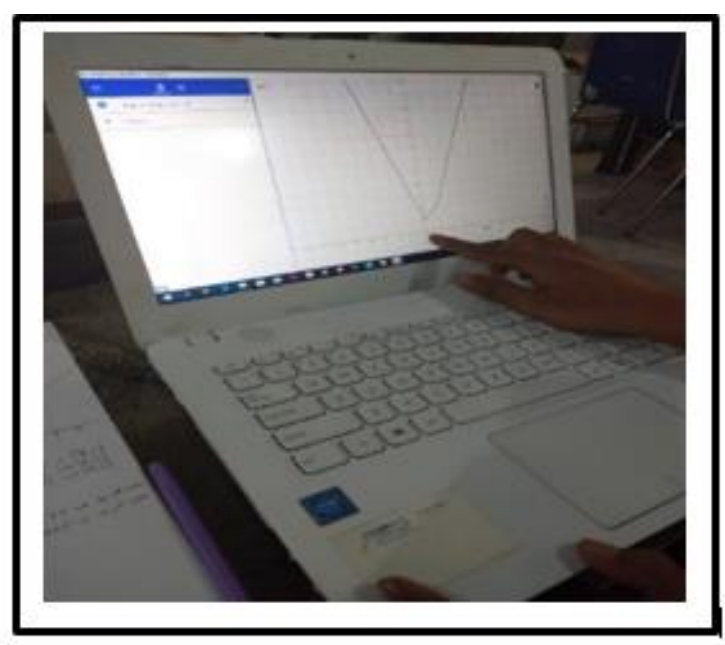

Gambar 1. Subjek menggunakan software Geogebra. 
software), selanjutnya muncul gambar grafiknya

P1P004 : eemm, coba jelaskan grafiknya ini (sambil menunjuk hasilnya di laptop)?

S1J004 : ini koordinat kartesius dengan skala satu satuan, lalu ini adalah titik $(0,0)$ yang menjadi pusat dari koordinat kartesius

P1P005 : bagaimana dengan model grafiknya?

S1J005 : kalau dari model grafiknya ini terbagi menjadi dua bagian yaitu ruas kirinya sumbu y, dan ruas kananya sumbu y, namun daerah kiri dan kanan ini berbeda

P1P006 : berbeda bagaimana maksudnya?

S1J006 : iya berbeda, yang sebelah kiri berupa garis lurus, tapai yang sebelah kanan ada seperti belok

P1P007 : kenapa bisa seperti itu?

S1J007 : iya karena ada dua nilai mutlak, dimana kedua berbeda, maka hasil grafiknya juga berbeda

Berdasarkan hasil wawancara di atas, subjek mengeksplorasi informasi soal dengan menggunakan software lebih menekankan adanya dua bentuk nilai mutlak dalam satu fungsi, sehingga mempengaruhi model grafik fungsi yang dihasilkan. Dari bentuk grafik yang dihasilkan, subjek melihat adanya dua ruas garis yang berbeda, dimana ruas garis sebelah kiri berupa garis lurus yang dipengaruhi fungsi nilai mutlak, sedangkan ruas garis sebelah kanan terdapat seperti berbelok.

\section{B. Aspek Teknologi (Technology)}

Aspek teknologi yaitu mengenai kemampuan subjek dalam menentukan software yang dapat mambantu penyelesaian masalah. Untuk mengetahui kemampuan subjek dalam penggunaan software dalam menyelesaikan soal, peneliti melakukan wawancara dengan subjek sebagai berikut.

P1P008 : software apa yang kamu gunakan untuk menyelesaikan soal nomor 2 ?

S1J008 : software Geogebra pak

P1P009 : kenapa kamu menggunakan Geogebra?

S1J009 : karena mudah menggunakannya

P1P010 : selain itu mas?

S1J010 : sebenarnya ada juga software matlab, tapi saya belum dapat mengoperasikkannya
P1P011 : ooo, jadi kamu sudah terbiasa menggunakan software Geogebra ya?

S1J011 : iya pak

P1P012 : apa Geogebra ini membantumu?

S1J012 : iya pak, tapi kita tidak tahu prosesnya karena hanya muncul hasilnya

P1P013 : apa kamu yakin dengan hasilnya?

S1J013 : iya pak

P1P014 : kenapa kamu yakin?

S1J014 : ya kalau kita lihat ini $x$ dimasukkan 0 maka nilai $y$-nya 1 dan seterusnya, makanya saya yakin

Berdasarkan hasil wawancara di atas, dapat diketahui bahwa subjek sudah terbiasa menggunakan aplikasi untuk membantu menyelesaikan masalah matematika. Namun, subjek mengungkapkan bahwa penggunaan software mempunyai kekurangan, yaitu tidak adanya proses penyelesaian. Sehingga perlu memastikan dengan mengecek setiap titik-titik yang dihasilkan guna memastikan nilai kebenarannya

\section{Aspek Teknik (Engineering)}

Aspek teknik yaitu mengenai kemampuan subjek dalam mengoperasikan software dalam mambantu penyelesaian masalah. Untuk mengetahui kemampuan subjek dalam menggunakan aplikasi, peneliti meminta subjek menunjukkan pengoperasian software Geogebra secara langsung. Subjek menjelaskan fungsi setiap fitur yang ada

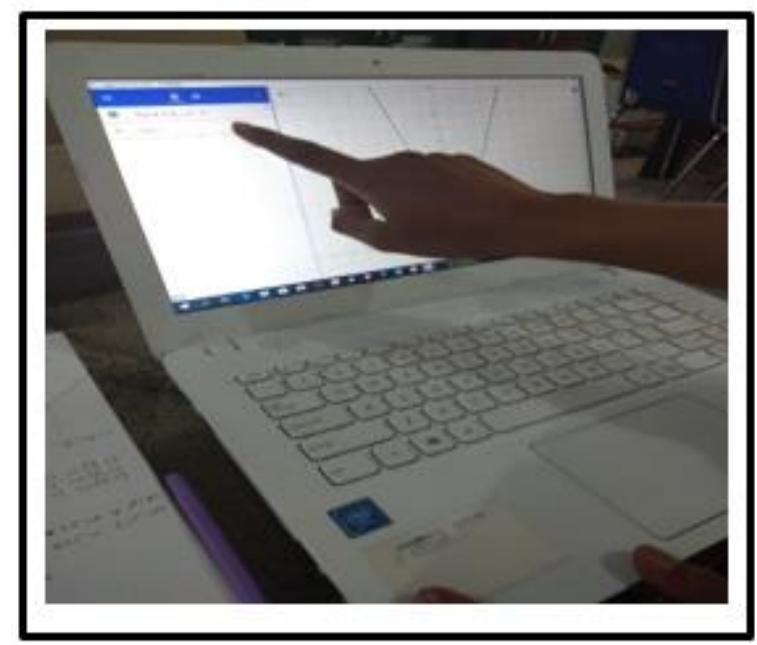

Gambar 2. Subjek menggunakan fitur-fitur software 
dalam software untuk membantu dalam menyelesaikan soal matematika (lihat gambar 2).

Dalam mengoperasikan software Geogebra, subjek menekankan jenis fungsi yang akan diinputkan pada program. Selanjutnya, subjek melakukan eksplorasi pada program Geogebra terutama grafik fungsi yang dihasilkan seperti mengubah skala dari koordinat kartesius, melakukan dilatasi pada objek yang dihasilkan, dan mengidentifikasi setiap titik-titik yang dilalui grafik. Hal itu ditunjukkan pada hasil wawancara antara peneliti dengan subjek sebagai berikut.

P1P015 : coba mas tunjukkan bagaimana kamu menggunakan aplikasi ini (software Geogebra)?

S1J015 : ini tadi hasil yang saya peroleh setelah inputkan fungsinya $f(x)=2|x|+$ $|x-1|$

P1P016 : ok, lalu?

S1J016 : ini kan gambarnya bisa saya ubah-ubah pak

P1P017 : maksudnya bagaimana mas?

S1J017 : jadi ini bisa dikecilkan atau dibesarkan pak gambarnya, dan juga bisa dilihat titiktitik disetiap garisnya sehingga mudah untuk mengeceknya apakah jawabanya benar atau ada yang kurang tepat. Tapi kalau pakai software selalu tepat (sambil tersenyum)

P1P016 : selain itu?

S1J016 : eem, ketika saya ubah angkanya seperti ini (sambil memperagakan) maka grafiknya juga akan berubah

Berdasarkan hasil jawaban dan wawancara di atas, subjek mampu mengoperasikan software Geogebra dengan baik. Hal itu ditunjunjukkan ketika subjek mengubah ukuran grafik yang ada di dalam aplikasi Geogebra. Selain itu, subjek mampu menunjukkan perubahan grafik yang disebabkan adanya perubahan fungsi.

\section{Aspek Matematika (Mathematics)}

Aspek Matematika yaitu mengenai kemampuan subjek dalam menganalisis dan menyampaikan gagasan untuk mendapatkan dan memeriksa simpulan Subjek melakukan analisis terhadap hasil yang diperoleh dan menyampaikan gagasan selama penyelesaian soal (lihat gambar 3).

Selanjutnya untuk mengkonfirmasi apa yang telah dilakukan oleh subjek, peneliti melakukan wawancara berbasis hasil jawaban. Hasil wawancara antara peneliti dengan subjek sebagai berikut.

P1P017 : apa yang kamu lihat dari hasilnya ini? (sambil menunjuk ke laptop)

S1J017 : ini saya lihat daerah sebelah kanan dari $y$, dimana garis yang dibentuk bukan garis lurus, melainkan agak sedikit berbelok, dan saya membandingkan dengan daerah sebelah kiri dari y, maka dapat dilihat untuk nilai yang sama pada kedua daerah

P1P018 : apa yang menyebabkan bisa berbeda?

S1J018 : ini karena ruas kiri untuk nilai mutlak dari $|x|$, sedangkan ruas kanan untuk $|x-1|$ sehingga itu yang menyebabkan grafik kedua ruas ini berbeda

P1P019 : lalu bagaimana dengan titik ini? (sambil menunjuk ke grafik)

S1J019 : eemmm, ini merupakan titik beloknya pak

P1P020 : maksudnya titik belok bagaimana mas?

S1J020 : sebenarnya ini ada dua titik belok pak, yang ini (sambil menunjuk titik koordinat $(0,1))$ dan ini pak (sambil menunjuk titik koordinat $(1,2))$

P1P021 : kenapa kok bisa seperti itu?

S1J021 : iya pak, karena ketika saya masukkan nilai $x=0$, maka nilai $\mathrm{y}=1$ dan sebelum itu terlihat grafiknya turun tapi setelah itu terlihat grafiknya naik lagi. Sedangkan jika saya masukkan nilai $x=1$ maka nilai $\mathrm{y}=$ 2 terlihat perubahan grafiknya, sehingga terdapat dua kali berbelok dari grafiknya

P1P022 : apa yang dapat kamu simpulkan?

S1J022 : ini ada dua titik koordinat yang penting

P1P023 : maksudnya penting bagaimana mas?

S1J023 : iya pak, karena kedua titi koordinat tersebut menyebabkan adanya dua titik belok, serta menyebabkan grafik nya tidak simetris. Mungkin itu juga 
dipengaruhi dari fungsinya juga (sambil tersenyum)

Berdasarkan Gambar 3 dan hasil wawancara, subjek menunjukkan beberapa hasil analisisnya terhadap hasil yang telah diperoleh penelitian Nopiyani dkk (2016) dan Mangelep (2017). Subjek menentukan titiktitik koordinat yang dianggap penting, karena titik tersebut menyebabkan adanya titik belok dari grafik fungsi yang telah dibuat. Selain itu, subjek mengungkapkan bahwa grafik fungsi yang dibentuk bukan merupakan grafik fungsi yang simetris. Artinya, grafik fungsinya tidak berlaku pencerminan, dan hal itu disebabkan pada fungsi yang diberikan.

Penalaran logis calon guru matematika dalam menyelesaikan masalah matematika yang dintegrasikan dengan pendekatan STEM menunjukkan bahwa pada aspek Sains (Science) yang menekankan kemampuan subjek dalam mengeksplorasi informasi sesuai dengan pengetahuan tentang nilai mutlak. Subjek mengidentifikasi fungsi $|x|$ dan $|x-1|$ mempengaruhi bentuk grafik ruas kiri dan ruas kanan. Sedangkan pada Aspek Teknologi (Technology) yang berkaitan dengan kemampuan subjek dalam menentukan software yang dapat membantu penyelesaian masalah dipengaruhi pengetahuan tentang beberapa software yang digunakan dalam matematika. Subjek menggunakan Software Geogebra untuk memecahkan soal matematika yang berkaitan dengan grafik. Selain itu, subjek mampu menguasai fitur-fitur dari software Geogebra. Subjek juga melakukan teknik dilatasi dan refleksi dari hasil yang diperoleh. Terakhir, Subjek juga mengevaluasi hasil yang ditunjukkan pada software Geogebra dengan melakukan subtitusi setiap titik yang diperoleh.

\section{Penutup}

Hasil penelitian ini menunjukkan bahwa pengintegrasian pendekatan STEM yang digunakan oleh subjek adalah dengan menggunakan aplikasi berupa software Geogebra. Subjek melakukan eksplorasi software Geogebra guna mengidentifikasi informasi-informasi yang diperlukan sesuai dengan pengetahuan yang dimiliki. Subjek juga melakukan beberapa teknik dalam mengoperasikan aplikasi Geogebra, seperti dilatasi dan refleksi. Selanjutnya subjek menekankan beberapa titik-titik koordinat selama membuat grafik fungsi tanpa atau dengan bantuan software Geogebra. Subjek meyakini kebenaran hasil yang ditunjukkan pada software Geogebra, karena sesuai dengan apa yang dikerjakan pada lembar jawaban.

Hal itu menunjukkan calon guru matematika dapat mengembangkan penalaran logis selama menyelesaikan soal matematika yang diintegrasikan dengan teknologi. Mahasiswa calon guru mampu mengembangkan keterampilan softskill terutama dalam menganalisis soal matematika yang disajikan dalam software Geogebra.

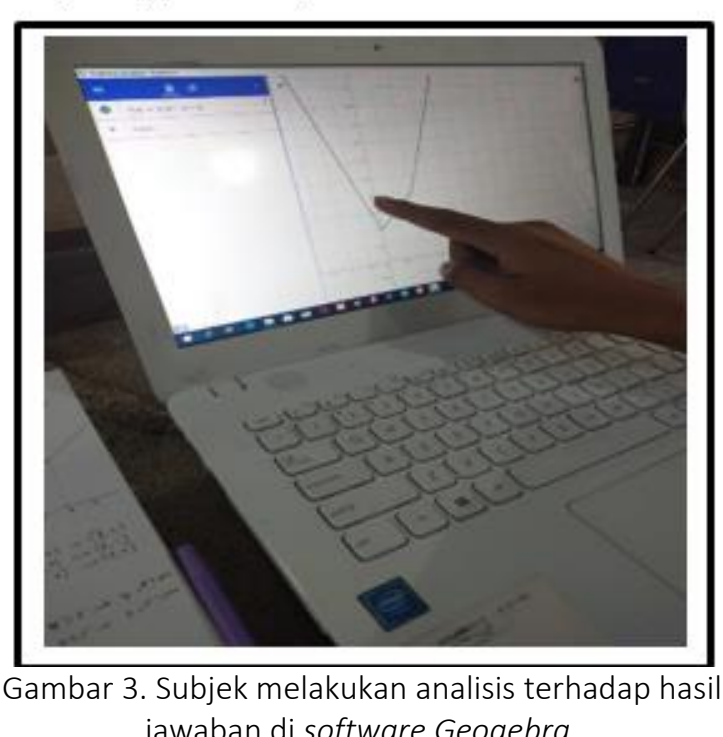
jawaban di software Geogebra. 
Terakhir, diharapkan mahasiswa calon guru mampu mengintegrasikan beberapa aplikasi atau software guna membantu penyelesaian soal matematika selama pembelajaran.

\section{Daftar Pustaka}

Afriansyah, E. A. (2016). The Use of Realistic Approach to Enhance Students' Mathematical Problem Solving Skills. International Conference on Elementary and Teacher Education ICETE.

Alam, Z. I., \& Razak, F. (2018). Pengembangan Lembar Kegiatan Siswa Berbasis Metode Penemuan Terbimbing Untuk Pembelajaran Matematika Pada Siswa Kelas XII SMA Negeri 1 Segeri. Mosharafa: Jurnal Pendidikan Matematika, 7(1). 1-12. DOI:

https://doi.org/10.31980/mosharafa.v7i1 Asrawati, N. (2012). Eksplorasi Kemampuan Penalaran dan Komunikasi Matematika Setelah Diterapkan Strategi Think-TalkWrite Setting Kooperatif Berdasarkan Gender PadaSiswaKelas X SMK Kartika XX1 Wirabuana Makassar. Tesis. Makassar: Program Pascasarjana UNM

Mangelep, N. O. (2017). Pengembangan Perangkat Pembelajaran Matematika Pada Pokok Bahasan Lingkaran Menggunakan Pendekatan Pmri Dan Aplikasi Geogebra. Mosharafa: Jurnal Pendidikan Matematika, 6(2), 193-200. DOI:

https://doi.org/10.31980/mosharafa.v6i2. $\underline{306}$

Mardiani, D. (2019). Model Accelerated Learnign Cycle Dalam Pembelajaran Pertidaksamaan Linier Dan Nilai Mutlak. Mosharafa: Jurnal Pendidikan Matematika, $\quad$ 8(3). $\quad$ 483-492.
DOI: https://doi.org/10.31980/mosharafa .v8i3.537

Nopiyani, D., Turmudi, \& Prabawanto, S. (2016). Penerapan Pembelajaran Matematika Realistik Berbantuan GeoGebra untuk Meningkatkan Kemampuan Komunikasi Matematis Siswa SMP. Mosharafa: Jurnal Pendidikan Matematika, 5(2), 45-52. DOI: https://doi.org/10.31980/mosharafa.v5i2. $\underline{259}$

Gonzalez, H. B. dan Kuenzi, J. J. (2012). Science, Technology, Engineering, and Mathematics (STEM) Education: A Primer. Congressional Research Service, 1-27 hlm. [Online],

(https://fas.org/sgp/crs/misc/R42642.pdf) , diakses 15 Juni 2019.

Permanasari, A. (2016). STEM Education: Inovasi dalam Pembelajaran Sains. Seminar Nasional Pendidikan Sains: Peningkatan Kualitas Pembelajaran Sains dan Kompetensi Guru Melalui Penelitian dan Pengembangan dalam Menghadapi Tantangan Abad-21, Universitas Pendidikan Indonesia, Bandung, 24-31 hIm.

(Online), (http://jurnal.fkip.uns.ac.id/index.php/snp s/ article/view/9810), diakses 15 Juni 2019.

Puspitasari \& Ratu, N. (2019). Deskripsi Pemahaman Konsep Siswa dalam Menyelesaikan Soal PISA pada Konten Space and Shape. Mosharafa: Jurnal Pendidikan Matematika, 8(1). 155-166. DOI: https://doi.org/10.31980/mosharafa. v8i1.431

Septiani, A. (2016). Penerapan Asesmen Kinerja dalam Pendekatan STEM (Sains, Teknologi, Engineering, Matematika) untuk Mengungkap Keterampilan Proses 
Sains. Seminar Nasional Pendidikan dan Saintek Isu-isu Kontemporer Sains, Lingkungan, dan Inovasi

Pembelajarannya, Universitas Pendidikan Indonesia, Bandung, 654-659 hlm. (Online),

(https://publikasiilmiah.ums.ac.id

/bitstream/handle/11617/7985/96.pdf?se quence=1), diakses 16 Juni 2019.

TIMSS. (2015). International Result in Since. International Study Center, 1-256 hlm

Rahadyan, A., Hartuti, P., M., \& Awaludin, A., A., R. (2018). Penggunaan aplikasi geogebra dalam pembelajaran matematika di sekolah menengah pertama. Jurnal PKM: Pengabdian kepada Masyarakat, 1(1). 11-19. DOI: http://dx.doi.org/10.30998/jurnalpkm.v1i 01.2357

Ramdhani, S. (2017). Kemampuan Penalaran Analogis Santri Dalam Geometri: Penelitian Kualitatif Di Sebuah Pondok Pesantren. Mosharafa: Jurnal Pendidikan Matematika, 6(3), 385-396. DOI: https://doi.org/10.31980/mosharafa. v6i3.327

Utami, N., T., Jatmiko, A., \& Suherman. (2018). Pengembangan Modul Matematika dengan Pendekatan Science, Technology, Engineering, And Mathematics (STEM) pada Materi Segiempat. Desimal: Jurnal Matematika, 1(2). 165-172. DOI: https://doi.org/10.24042/djm.v1i2.2388

Utomo, E.S., Rahman, F. (2016). Pengaruh Model Pembelajaran Kooperatif Tipe Pair Check Terhadap Hasil Belajar Siswa. Diambil kembali http://seminar.uny.ac.id/semnasmatemat ika/sites/seminar.uny.ac.id.semnasmatem atika/files/PM-7.pdf.
Winarni, J., Zubaidah, S., \& Koes, S. (2016). STEM: Apa, Mengapa, Dan Bagaimana. Prosiding Semnas Pend IPA Pascasarjana UM. http://pasca.um.ac.id/wpcontent/uploads/2017/02/Juniaty-

Winarni-976-984.pdf

\section{Riwayat Hidup PenUlis \\ Dr. Edy Setiyo Utomo, M.Pd.}

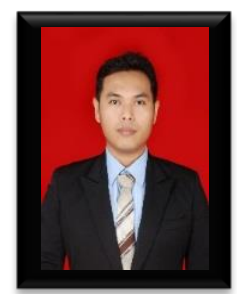

Lahir di Jombang, 05 Desember 1984. Pengajar di STKIP PGRI Jombang. Studi S1 Pendidikan Matematika STKIP PGRI Jombang, Jombang, lulus tahun 2008; S2 Pendidikan Matematika Universitas Negeri Surabaya, Surabaya, lulus tahun 2013; dan S3 Pendidikan Matematika Universitas Negeri Surabaya, Surabaya, lulus tahun 2018. Publikasi Artikel: Mathematical visualization process of junior high school students in solving a contextual problem based on cognitive style; Exploring Aspects of Mathematical Visualization of Junior High School Student in a Problem-Solving Task.

\section{Fatchiyah Rahman, M.Pd.}

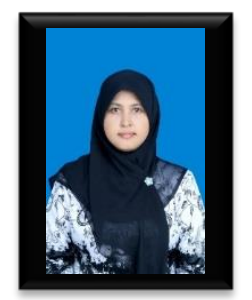

Lahir di Jombang, 12 Februari 1982. Studi S1 Pendidikan Matematika STKIP PGRI Jombang, Jombang, lulus tahun 2005; S2 Pendidikan Matematika Universitas Negeri Surabaya, Surabaya, lulus tahun 2013.

\section{Ama Noor Fikrati, M.Pd.}

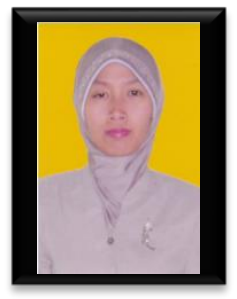

Lahir di Jombang, 8 Februari 1981. Studi S1 Pendidikan Matematika STKIP PGRI Jombang, Jombang, lulus tahun 2003; S2 Pendidikan Matematika Universitas Negeri Surabaya, Surabaya, lulus tahun 2006 